\title{
"Asuggest Vision For Establishing A Special Unit For Sports Shoes In The Faculties Of Physical Education In The Arab Republic Of Egypt In Light Of The 2030 Sustainable Development Goals"
}

\section{Prof.Dr Rania Morsy Abo El-abas Abd El-aziz}

Professor of motor expression, Department of sport Administration \& Recreation, Assiut University-Faculty of Physical Education

\section{Dr. Naglaa Fathy Ahmed Hamdan}

Instructor of motor expression, Department of sport Administration \& RecreationFaculty of Physical Education - New Valley University

\section{Abstract}

The study aimed to develop a suggested vision for establishing a special unit for sports shows in the faculties of physical education in the Arab Republic of Egypt in light of the 2030 Sustainable Development Goals, the researcher used the descriptive approach, the sample included some university presidents and university agents for community service affairs, environmental development, deans, agents and faculty members in the faculties of physical education For community service and environmental development affairs, directors of the Department of Community Affairs and Environmental Development, the board of directors of some units in some Egyptian universities in the Arab Republic of Egypt which reached about (160) Individuals . The most important results is A suggested vision for establishing a special unit for sports shows included proposed vision, as it included the vision, mission, objectives of the unit, and the basic bylaw for establishing the unit, as it included (administrative regulation - technical regulation - Financial Regulation Legislative Regulation).

Key words: SPECIAL UNIT, SPORTS SHOES, COMMUNITY SERVICE, SELF-RESOURCES, THE 2030 SUSTAINABLE DEVELOPMENT.

\section{Introduction and research problem:}

The university is considered the basis for the progress of societies, as it is a beacon of science, research and culture, where it adopted society's thought and culture in various fields and disciplines, as the function of community service became one of the basic functions that the university undertakes to interact with society, its role is no longer limited to education and scientific research only.

It is the responsibility of the community service and environmental affairs sector in Egyptian universities to serve the community, as it undertakes many tasks and activities related to society, by establishing centers and special units in the fields of education, scientific research and community service, and these units have appeared officially according to law no. (345) of 1956, which was later replaced by Law no. (49) Of 1972, which approved the establishment of special units in the universities by a decision of the University Council, where these units provide training, research, environmental, and production services to various community institutions? (13:10) 
The concept of special units appears in the transformation of universities into an effective entity in the national economy, as the activity of self-resource development has become one of the university's responsibilities, especially with the current conditions the country is going through, and these units contribute to solving many problems, whether economic or social, so they work to confront Lack of financial resources, in order to advance the educational and research process that would serve the community, which contributes to reducing the burden on the state budget. ( $($ q: 96 )

The faculty of Physical Education is one of the educational institutions within the university, as it is the source of culture and sports enlightenment and upgrading the level of sports and athletes in society, and it will not be possible for them to upgrade this important and vital role except through improving and developing the quality of services provided in the sports field in particular and society in general, and the development of a mechanism To develop the activities of the faculty in the field of community service and environmental development, by activating the role of special units and centers for faculties, including the public service center, with the aim of providing financial support and self-financing to faculties and the university.

( ) r: 6)

In light of the above, Egyptian universities in general and faculties of physical education in particular have tended to establish special units as a necessity to provide various service activities to various society institutions, participate in the development of human resources and provide the needs of society and additional funding sources to improve the level of services in them to raise the efficiency of their outputs and maintain their entity, independence and legitimacy And increase the available means for the university to achieve its goals in serving the community and dealing with its various sectors.

All of that called for an attempt to create more special units of within the faculties of physical education, which contribute to the advancement of its various fields, including the field of sports shows, where sports shows have become (Abdel- Khalek; 2015) a free standing field in the fields of physical education, so Countries pay attention to it and has become a scientific method that scientists around the world take in research, development and innovation. ( $Y$ T: 35 )

Through the work of the two researchers as a member and body teaching and in the field of sports shows and as members of the Committee for Community Service and Environmental Development we noticed that the social services provided by faculties of physical education from public service centers are limited to some activities only 
(football, gymnastics, karate, swimming, boxing, and wrestling) without paying attention to the rest of the areas Including sports shows.

In light of the social and economic developments, the importance of the special units of in serving their society as an alternative to financing, and this was indicated in the study of (Mabrouk; 2019) ( $r$ r) and (zaham; 2016) $(r \cdot)$ about the necessity of establishment of the special units and their role should be activated as these units are The basic open-minded and interactive window with the community.

Hence the idea of this research came to a suggested vision for a special unit for sports shows in an attempt to search for new sources to contribute to the self-financing of the faculties of physical education through investing the activities of this unit and marketing its services to benefit the community.

\section{Importance and need for research:}

1- Contribute to providing new sources of self-resources for Physical Education Colleges.

2- Contributing to the development of fields related to sports shows and their workers.

3- Establishing new programs provided by the Faculties of Physical Education in the field of community service and environmental development.

\section{Research objectives:}

The research aims to develop a suggested vision for establishing a special unit for sports shows by identifying:

1- Unit name.

2- Seeing the unit.

3- Unity message.

4- Unit goals.

5- The basic bylaw for establishing the unit (administrative, technical, financial, legislative and legal).

\section{Research questions:}

1- What is the name of the unit?

2- What is the seeing of unity?

3 - What is the message of unity?

4-What are the unit goals?

5- What are the basic regulations for establishing the unit (administrative, technical, financial, legislative and legal)?

The terms mentioned in the research:

Sports Special Unit: (procedural definition) Centers and Special Units

These are independent administrative financial services systems in the field of sports shows in the faculties of physical education that contribute 
effectively to community service and self-financing and dependence on their financial resources in implementing their programs and activities.

\section{Some related studies:}

1- The study conducted by (AL Saad;2018) (1) aimed to: activating the role of units of a special nature in light of their goals and the experience of American universities, the researcher used the descriptive approach, the research sample included some units of a special nature in some colleges at Aim Shams University and Mansoura University and some university experiences In both the United States of America and Malaysia, and for students who benefit from its services, one of the most important results reached is that the units are created according to general and comprehensive planning linked to the overall development of the community surrounding universities and the achievement of the national interest, and that the programs and activities of the units are developed according to the needs of the beneficiaries of students To their satisfaction.

2- The study conducted by (Issa;2018) ( $\left.r^{\prime}\right)$ aimed to: identifying the relationship between Palestinian universities and local community institutions, the researcher used the descriptive approach, the research sample included the university president and heads of departments and director of the Community Partnership Institute in universities and some experts in civil society institutions and field work team coordinators In civil institutions in Palestine, and one of the most important results reached is the existence of strong relationships between universities and civil society institutions in the cultural, educational and social aspects, and civil society institutions play an important role in achieving sustainable development in the university work sector by providing material support to universities.

3- The study conducted by (Awad;2018) (11) aimed: identifying the role of university units of a special nature in community service and environmental development, the researcher used the descriptive approach, the sample included some units of a special nature that provide services to society and environment development in Egyptian universities, and from The most important results that were reached setting a proposed vision for developing the function of community service and developing the environment in Egyptian universities.

4- The study conducted by (Rajab;2018) $(r \wedge)$ aimed to: identifying the role of the social responsibility of the university and how it affected society, the researchers used the descriptive approach, the research sample included (UTM) University of Engineering Science and Technology in Malaysia, and one of the most important results that were 
reached It concluded that the fields of sports, recreation, health care, volunteer work, capacity building and social care were among the most important roles of the university's social responsibility towards society.

5- The study conducted by (Arnold;2018) (1•) aimed to: identifying the role of colleges in enhancing support for improving student transition after graduation to a professional life in society at Pepperdine University in the United States of America, the researcher used the descriptive approach, the research sample included some colleges and some departments in it That focuses on helping students on their trips to careers and some of the students in these departments, and one of the most important results reached is that one of the most important ways to support students is to integrate programs and activities across departments to improve the services provided.

\section{Comment on related studies:}

After examining the related studies and analyzing their data, Researchers were able to benefit from them in identifying:

1- Formulating goals and setting research questions.

2- The best suitable procedures that can help achieve the research objectives.

3- Choosing the means and tools of data collection appropriate for the current study.

\section{Research Methodology:}

The researcher used the descriptive approach as it suits the nature of the study.

\section{Research Population:}

The research Population consists of university presidents, university agents for community service affairs and environmental development, deans and agents of the college for community service and environmental development affairs, faculty members specializing in sports shows in the faculties of physical education, directors of community affairs follow-up and environmental development, and the board of directors of some special units to some Egyptian universities in the Arab Republic of Egypt.

\section{Research Sample:}

The research sample was randomly chosen from the research Population, and Table (1) shows the description of the research sample.

Table (1)

Description of the research sample

\begin{tabular}{c|l||c|c}
\hline \hline No. & \multicolumn{1}{|c||}{ Sample } & Fundamental & Exploratory \\
\hline \hline $\mathbf{1}$ & Heads of Egyptian universities. & $\mathbf{8}$ & $\mathbf{3}$ \\
\hline $\mathbf{2}$ & $\begin{array}{l}\text { Egyptian university agents for community service and } \\
\text { environmental development affairs in Egyptian universities. }\end{array}$ & $\mathbf{8}$ & $\mathbf{3}$ \\
\hline
\end{tabular}




\begin{tabular}{c|l||c|c}
\hline $\mathbf{3}$ & $\begin{array}{l}\text { deans of the faculties of physical education in the Egyptian } \\
\text { universities }\end{array}$ & $\mathbf{1 2}$ & $\mathbf{4}$ \\
\hline $\mathbf{4}$ & $\begin{array}{l}\text { agents of faculties of physical education for community service } \\
\text { and environmental development affairs in Egyptian universities }\end{array}$ & $\mathbf{1 2}$ & $\mathbf{4}$ \\
\hline $\mathbf{5}$ & $\begin{array}{l}\text { members of the teaching staff who specialize in sports shows in } \\
\text { faculties of physical education. }\end{array}$ & $\mathbf{3 0}$ & $\mathbf{6}$ \\
\hline $\mathbf{6}$ & $\begin{array}{l}\text { directors of the Department of Community Affairs and } \\
\text { Environmental Development in the Egyptian universities. }\end{array}$ & $\mathbf{1 0}$ & $\mathbf{5}$ \\
\hline $\mathbf{7}$ & $\begin{array}{l}\text { members of the Board of Directors of the special units in the } \\
\text { Egyptian universities. }\end{array}$ & $\mathbf{8 0}$ & $\mathbf{5}$ \\
\hline \hline & Total & $\mathbf{1 6 0}$ & $\mathbf{3 0}$ \\
\hline \hline
\end{tabular}

\section{Tools of Data collection:}

1- The regulations of some Egyptian universities and colleges for units of a special nature

2- The Egyptian Universities Organization Law and its executive regulations

3- The questionnaire:

\section{- The questionnaire:}

Based on the research problem and its objectives, the two researchers designed number (2) questionnaires to identify:

1- The name, seeing, message and goals of the unit.

2- The unit's basic bylaw (administrative - technical - financial - legal and legislative).

\section{1- The name, seeing, message and goals of the unit.}

\section{First: Defining the axes of the questionnaire:}

To determine the scientific references and related studies and some regulations for special units were analyzed, where (4) axes were reached, and then presented to the experts attached (1) to express their views on them.

Table (2)

The percentage of expert opinions on the questionnaire's axes $(n=8)$

\begin{tabular}{c|lc||c}
\hline \hline No. & \multicolumn{1}{c||}{ Suggested axes } & percentage \\
\hline \hline $\mathbf{1}$ & Unit name. & $\mathbf{1 0 0 \%}$ \\
\hline $\mathbf{2}$ & Seeing the unit. & $\mathbf{1 0 0 \%}$ \\
\hline $\mathbf{3}$ & Unity message. & $\mathbf{1 0 0 \%}$ \\
\hline $\mathbf{4}$ & Unit goals. $\quad$ ALL & $\mathbf{1 0 0 \%}$ \\
\hline \hline
\end{tabular}

Table (2) showed that the experts agree on all the proposed axes. Second: Preparing phrases of the Questionnaire:

The questionnaire was put in its initial form attachment (3), which included (4) phrases, and then it was presented to the experts Attachment (1). 
Table (3)

The percentage of expert opinions on the questionnaire's ferries $(n=8)$

\begin{tabular}{|c|c|c|c|}
\hline Axes & NO & Ferries & $\%$ \\
\hline Unit name: & 1 & Scientific Center for Sports Shows. & $100 \%$ \\
\hline $\begin{array}{c}\text { Seeing the } \\
\text { unit: }\end{array}$ & 2 & $\begin{array}{l}\text { The Scientific Center for Sports Shows is a leading center at the local and } \\
\text { regional levels in providing administrative and technical services and } \\
\text { consultations for sports shows. }\end{array}$ & $100 \%$ \\
\hline $\begin{array}{c}\text { Unity } \\
\text { message: }\end{array}$ & 3 & $\begin{array}{l}\text { The center seeks to provide services to individuals and various institutions inside } \\
\text { and outside the university in the field of Sports Shows to meet the diverse needs } \\
\text { of society. }\end{array}$ & $100 \%$ \\
\hline \multirow{4}{*}{ Unit goals: } & 4 & $\begin{array}{l}\text { Conducting scientific research in the field of sports performances } \\
\text { Marketing of Sports Shows. }\end{array}$ & $100 \%$ \\
\hline & 5 & Providing administrative and technical consultations in the field of Sports Shows. & $100 \%$ \\
\hline & 6 & Providing training programs and courses in the field of sports shows. & $100 \%$ \\
\hline & 7 & Holding scientific seminars and conferences in the field of Sports Shows. & $100 \%$ \\
\hline
\end{tabular}

Table (3) showed that the experts agree on all the all suggested phrases.

\section{Third: The Exploratory Study:}

The Researchers conducted an exploratory study on a sample of (30) from the research population and outside the basic research sample.

Fourth: The scientific transactions of the questionnaire:

\section{1- Validity:}

The Researchers applied the questionnaire to the survey sample and calculated the correlation coefficient between the degree of the single phrase and the total degree of the axis to which it belongs, as well as calculating the correlation coefficient between the degree of the single axis and the total degree of the questionnaire.

\section{Table (4)}

Correlation coefficient between phrases and the overall degree of the axis to which you belong (n $=30$ )

\begin{tabular}{|c|c|c|c|}
\hline Axes & NO & Ferries & COR. \\
\hline Unit name: & 1 & Scientific Center for Sports Shows. & $* *, \vee r q$ \\
\hline $\begin{array}{l}\text { Seeing the } \\
\text { unit: }\end{array}$ & 2 & $\begin{array}{l}\text { The Scientific Center for Sports Shows is a leading center at the local and } \\
\text { regional levels in providing administrative and technical services and } \\
\text { consultations for sports shows. }\end{array}$ & $* *,, \vee \vee 1$ \\
\hline $\begin{array}{l}\text { Unity } \\
\text { message: }\end{array}$ & 3 & $\begin{array}{l}\text { The center seeks to provide services to individuals and various institutions } \\
\text { inside and outside the university in the field of Sports Shows to meet the } \\
\text { diverse needs of society. }\end{array}$ & $* *, \wedge) 1$ \\
\hline \multirow{4}{*}{ Unit goals: } & 4 & $\begin{array}{l}\text { Conducting scientific research in the field of sports performances } \\
\text { Marketing of Sports Shows. }\end{array}$ & $* *,, \vee \neg \leq$ \\
\hline & 5 & $\begin{array}{l}\text { Providing administrative and technical consultations in the field of Sports } \\
\text { Shows. }\end{array}$ & $* *, \wedge 9 \varepsilon$ \\
\hline & 6 & Providing training programs and courses in the field of sports shows. & $* *, \wedge \neg 7$ \\
\hline & 7 & Holding scientific seminars and conferences in the field of Sports Shows. & $* *, \vee \vee \wedge \neg$ \\
\hline
\end{tabular}

It is clear from Table (4) that the correlation coefficient between the expressions and the overall degree of the axis to which it belongs ranges 
between $(\bullet, \vee \curlyvee 9 * *$ : $0 . \wedge 9 \leqslant * *)$ and all these statements are statistically significant at the level (0.05), which indicates the validity of the questionnaire.

\section{2- Stability:}

The Researchers calculated the stability coefficient for the questionnaire using the "Alpha Cronbach" factor, by calculating the alpha coefficient for each axis as well as for the questionnaire as a whole.

Table (5)

Calculation of stability using the alpha and mid-segmentation coefficients of the survey axes $(\mathbf{n}=30)$

\begin{tabular}{|c|c|c|c|c|c|}
\hline \multirow{2}{*}{ No. } & \multirow{2}{*}{ Axes } & \multirow{2}{*}{ Alpha } & \multirow{2}{*}{ COR. } & \multicolumn{2}{|c|}{ FIX.FAS. } \\
\hline & & & & SP.- BRO. & GETT \\
\hline & $\overline{\text { ALL }}$ & $\overline{c \cdot, \wedge 65}$ & $2,7,749$ & '•,857 & $\overline{c, \wedge 45}$ \\
\hline
\end{tabular}

It is clear from Table (5) which are statistically significant coefficients at (0.05) level, which indicates that the questionnaire has high stability coefficients.

\section{Fifth: The application of the questionnaire:}

After confirming the scientific transactions of the questionnaire, the questionnaire was applied in its final form attachment (4) to the basic sample in the period form $1 / 9 / r \cdot 19$ to $30 / 11 / 2019$.

2- The unit's basic bylaw (administrative - technical - financial - legal and legislative).

First: Defining the axes of the questionnaire:

To determine the scientific references and related studies were analyzed, where (4) axes were reached, and then presented to the experts attached (1) to express their views on them.

\section{Table (6)}

The percentage of expert opinions on the questionnaire's axes $(n=8)$

\begin{tabular}{|c|c|c|c|c|}
\hline No. & Suggested axes & W.S & W.S.D & percentage \\
\hline \multicolumn{2}{|c|}{ The first axis: administrative regulation } & $r, 99$ & $1, \ldots$ & $99,0 \leq$ \\
\hline 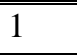 & Organizational structure of the unit & r,q1 & $\cdot, 9 \mathrm{~V}$ & qV,Ir \\
\hline 2 & Jurisdictions of the board of the unit & r, $9 \leq$ & $\cdot, 9 \wedge$ & $9 \wedge, 11$ \\
\hline \multicolumn{2}{|c|}{ Second axis: technical regulation } & r,qr & $\cdot, 9 \mathrm{~V}$ & $9 \vee, \varepsilon$. \\
\hline 3 & Establishment goals of the unit & 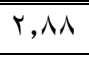 & $\cdot, 97$ & $90, \wedge r$ \\
\hline 4 & Rules and principles of the unit & r,9V & $\cdot, 99$ & 91,97 \\
\hline 5 & Tasks and activities of the unit & r,qr & $\cdot, 91$ & $9 \vee, V T$ \\
\hline \multicolumn{2}{|c|}{ Third axis: financial regulation } & $r, q \mathrm{~V}$ &., 99 & $99, \cdots$ \\
\hline \multicolumn{2}{|c|}{ Fourth axis : legislative regulation } & $r, \ldots$ & $1, \ldots$ & $1 \ldots, \ldots$ \\
\hline & ALL & $Y, 97$ & $\cdot, 99$ & $9 \wedge, 01$ \\
\hline
\end{tabular}

Table (6) showed that the percentage of experts agreeing on the axes ranged (97.12\%: 100\%), and thus all the proposed axes were approved.

\section{Second: Preparing phrases of the Questionnaire:}

The questionnaire was put in its initial form attachment (6), which 
included (90) phrases, and then it was presented to the experts Attachment (1).

Table (7)

The percentage of expert opinions on the questionnaire's ferries $(n=8)$

\begin{tabular}{|c|c|c|c|c|c|c|c|c|c|c|c|c|}
\hline Axes & NO & $\%$ & NO & $\%$ & NO & $\%$ & NO & $\%$ & NO & $\%$ & NO & $\%$ \\
\hline \multirow{4}{*}{$\begin{array}{l}\text { The first } \\
\text { axis: } \\
\text { administr } \\
\text { ative } \\
\text { regulation }\end{array}$} & 1 & $100 \%$ & 2 & $87.5 \%$ & 3 & $100 \%$ & 4 & $100 \%$ & 5 & $\% 100$ & 6 & $100 \%$ \\
\hline & 7 & $100 \%$ & 8 & $100 \%$ & 9 & $100 \%$ & 10 & $87.5 \%$ & 11 & $100 \%$ & 12 & $100 \%$ \\
\hline & 13 & $100 \%$ & 14 & $87.5 \%$ & 15 & $100 \%$ & 16 & $87.5 \%$ & 17 & $87.5 \%$ & 18 & $100 \%$ \\
\hline & 19 & $100 \%$ & 20 & $100 \%$ & 21 & $87.5 \%$ & 22 & $100 \%$ & & & & \\
\hline \multirow{6}{*}{$\begin{array}{l}\text { Second } \\
\text { axis: } \\
\text { technical } \\
\text { regulation }\end{array}$} & 23 & $100 \%$ & 24 & $100 \%$ & 25 & $100 \%$ & 26 & $100 \%$ & 27 & $100 \%$ & 28 & $100 \%$ \\
\hline & 29 & $87.5 \%$ & 30 & $87.5 \%$ & 31 & $87.5 \%$ & 32 & $100 \%$ & 33 & $100 \%$ & 34 & $100 \%$ \\
\hline & 35 & $100 \%$ & 36 & $100 \%$ & 37 & $100 \%$ & 38 & $100 \%$ & 39 & $100 \%$ & 40 & $100 \%$ \\
\hline & 41 & $100 \%$ & 42 & $100 \%$ & 43 & $100 \%$ & 44 & $100 \%$ & 45 & $100 \%$ & 46 & $100 \%$ \\
\hline & 47 & $87.5 \%$ & 48 & $100 \%$ & 49 & $100 \%$ & 50 & $87.5 \%$ & 51 & $100 \%$ & 52 & $100 \%$ \\
\hline & 53 & $100 \%$ & 54 & $100 \%$ & 55 & $100 \%$ & & & & & & \\
\hline \multirow{5}{*}{$\begin{array}{l}\text { Third axis: } \\
\text { financial } \\
\text { regulation }\end{array}$} & 56 & $100 \%$ & 57 & $100 \%$ & 58 & $87.5 \%$ & 59 & $100 \%$ & 60 & $100 \%$ & 61 & \\
\hline & 62 & $87.5 \%$ & 63 & $87.5 \%$ & 64 & $100 \%$ & 65 & $100 \%$ & 66 & $87.5 \%$ & 67 & $87.5 \%$ \\
\hline & 68 & $100 \%$ & 69 & $87.5 \%$ & 70 & $100 \%$ & 71 & $100 \%$ & 72 & $100 \%$ & 73 & $87.5 \%$ \\
\hline & 74 & $87.5 \%$ & 75 & $87.5 \%$ & 76 & $100 \%$ & 77 & $100 \%$ & 78 & $100 \%$ & 79 & $100 \%$ \\
\hline & 80 & $100 \%$ & & & & & & & & & & \\
\hline \multirow{3}{*}{$\begin{array}{l}\text { Fourth axis } \\
\text { : legislative } \\
\text { regulation }\end{array}$} & 81 & $100 \%$ & 82 & $87.5 \%$ & 83 & $100 \%$ & 84 & $87.5 \%$ & 85 & $87.5 \%$ & 86 & \\
\hline & 87 & $87.5 \%$ & 88 & $100 \%$ & 89 & $100 \%$ & 90 & $87.5 \%$ & 91 & $100 \%$ & 92 & \\
\hline & 93 & $100 \%$ & 94 & $100 \%$ & 95 & $100 \%$ & & & & & & \\
\hline
\end{tabular}

It is clear from Table (7) the percentage of expert opinions ranged between $(87.5 \%: 1 \cdots \%)$, as all the proposed phrases were agreed upon.

\section{Third: The Exploratory Study:}

The Researchers conducted an exploratory study on a sample of (30) from the research population and outside the basic research sample.

\section{Fourth: The scientific transactions of the questionnaire:}

\section{1- Validity:}

The Researchers applied the questionnaire to the survey sample and calculated the correlation coefficient between the degree of the single phrase and the total degree of the axis to which it belongs, as well as calculating the correlation coefficient between the degree of the single axis and the total degree of the questionnaire.

Table (8)

Correlation coefficient between phrases and the overall degree of the axis to which you belong (n $=30$ )

\begin{tabular}{|c|c|c|c|c|c|c|c|c|c|}
\hline NO & COR. & NO & COR. & NO & COR. & NO & COR. & NO & COR. \\
\hline \multicolumn{2}{|c|}{ Organizational } & 19 & $* *,, \vee \circ \leq \leqslant$ & rV & $* *,, \vee \vee \neg$ & \multicolumn{2}{|c|}{ financial } & $V 7$ & $* *,, \wedge \leq \varepsilon$ \\
\hline 1 & $* *, V \leq 0$ & $r$. & $* *, 9,1$ & r & $* *, \vee \vee \wedge \varepsilon$ & 07 & $* *,, \vee \wedge \varepsilon$ & $V V$ & $* *, \vee \vee \varepsilon$. \\
\hline
\end{tabular}




\begin{tabular}{|c|c|c|c|c|c|c|c|c|c|}
\hline$r$ & $* *,, \vee \circ \leq$ & YI & $* *,, \vee \circ \wedge$ & rq & $* *,, \vee 90$ & ov & $* *,, \vee \circ \leq$ & V^ & $* *,, \vee \neg 9$ \\
\hline$r$ & $* *, \wedge \cdot 1$ & rr & $* *,, \vee 0 \leq$ & \multicolumn{2}{|c|}{$\begin{array}{c}\text { Tasks and } \\
\text { activities } \\
\end{array}$} & $0 \wedge$ & 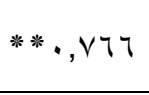 & $\vee q$ & $* *,, \vee \wedge \wedge$ \\
\hline$\varepsilon$ & $* *,, 709$ & \multicolumn{2}{|c|}{ goals } & $\varepsilon$ & $* *, \wedge r\urcorner$ & 09 & **,, ו ו & $\wedge$ & $* *,, \vee 00$ \\
\hline 0 & $* *, v \cdot 1$ & rr & $* *, V Y I$ & $\varepsilon 1$ & $* *, \wedge) \leq$ & 7. & $* *, \wedge I r$ & \multicolumn{2}{|c|}{ Legislative } \\
\hline 7 & $* *, \vee \vee \vee q$ & $r \leq$ & $* *, \vee \vee 79$ & $\varepsilon r$ & $* *,, \vee 0 \varepsilon$ & 71 & $* *, \vee \vee T 1$ & $\wedge 1$ & $* *, \wedge \leq \vee$ \\
\hline V & **, , VTr & ro & $* *, \wedge I r$ & $\varepsilon r$ & $* *, \vee \vee \wedge \wedge$ & Tr & $* *, \vee \backslash 1$ & Nr & $* *,, \vee 07$ \\
\hline$\wedge$ & $* *, \vee \vee \leqslant 9$ & $r$ & $* *, 9 \cdot 1$ & $\varepsilon \varepsilon$ & $* *, v \leq 1$ & תוד & $* *, \wedge \cdot \varepsilon$ & N & $* *, \vee \vee \wedge \varepsilon$ \\
\hline 9 & $* *, \wedge 01$ & rV & $* *, \wedge 97$ & $\varepsilon 0$ & $* *, 7 \wedge 9$ & $7 \leq$ & $* *, 9 \ldots$ & $\wedge \varepsilon$ & $* *, \wedge \wedge \varepsilon$ \\
\hline \multicolumn{2}{|c|}{ Jurisdictions } & rᄉ & $* *, \Lambda r r$ & $\leqslant 7$ & $* *$, , vor & 70 & $* *,, \uparrow \wedge \vee$ & 10 & $* *,, \vee \vee \varepsilon$ \\
\hline 1 & $* *, \vee \vee ० 9$ & rq & $* *, \vee v \leq 1$ & $\varepsilon V$ & $* *, \vee \vee 9 \wedge$ & $7 V$ & $* *, \vee \vee \wedge \varepsilon$ & 17 & $* *, 901$ \\
\hline 11 & **, • & r. & $* *,, \vee 00$ & $\varepsilon \wedge$ & $* *,, \vee 00$ & 71 & $* *$, , $\vee 07$ & $\Lambda V$ & $* *,, 70 \mathrm{~V}$ \\
\hline ir & $* *, \wedge I r$ & \multicolumn{2}{|c|}{ Rules } & $\leqslant 9$ & $* *, V Y T$ & 79 & $* *,, \vee \wedge I$ & $\wedge \wedge$ & $* *, \wedge \leq 0$ \\
\hline r & $* *, \vee \vee \backslash 0$ & ו & **, • & 0. & $* *,, \vee \neg \wedge$ & $v \cdot$ & $* *,, V \vee r$ & 19 & $* *,, \vee \circ \wedge$ \\
\hline $1 \leq$ & $* *, \wedge) \leq$ & r & $* *, \wedge \wedge r$ & 01 & **, , & $v_{1}$ & $* *, \vee \vee \vee$ & 9. & $* *, \wedge \wedge r$ \\
\hline 10 & **, • & سץ & $* *, \vee \vee \neg 7$ & or & $* *,, \vee>0$ & VY & $* *, \wedge) \leq$ & 91 & $* *,, \vee \neg 0$ \\
\hline 17 & $* *, \wedge 11$ & $r \varepsilon$ & $* *,, \vee \backslash 9$ & or & $* *,, \vee ৭ \wedge$ & $v r$ & $* *, \vee \vee ৭ 9$ & $q r$ & $* *,, \vee \circ \leq$ \\
\hline iv & $* *$, , vor & ro & $* *, \wedge \backslash \vee$ & $0 \leqslant$ & $* *, V \backslash)$ & $v \leq$ & $* *, \vee \vee \neg \wedge$ & מי & $* *, V \backslash Y$ \\
\hline \multirow[t]{2}{*}{11} & $* *, 91 \leq$ & דr & $* * \cdot, V T V$ & 00 & $* *$, VYO & vo & $* *, \wedge \leq 0$ & $9 \leq$ & $* *,, \vee \cdots$ \\
\hline & & & & & & & & 90 & $* *,, \vee \wedge \varepsilon$ \\
\hline
\end{tabular}

It is clear from Table (8) that the correlation coefficient between the expressions and the overall degree of the axis to which it belongs ranges between $(\cdot, 709 * *$ : $0.914 * *)$ and all these statements are statistically significant at the level (0.05), which indicates the validity of the questionnaire.

Table (9)

Correlation coefficient between axes and the overall score of the questionnaire $(n=30)$

\begin{tabular}{c||l||c}
\hline \hline No. & \multicolumn{1}{|c||}{ Axes } & CORR.COE \\
\hline \hline $\mathbf{1}$ & The first axis: administrative regulation. & $* * 0.884$ \\
\hline $\mathbf{2}$ & Second axis: technical regulation. & $* *,, \vee \uparrow \varepsilon$ \\
\hline $\mathbf{3}$ & Third axis: financial regulation. & $* *$, ヘ $~$ \\
\hline $\mathbf{4}$ & Fourth axis: legislative regulation. & $* *$, q) \\
\hline \hline
\end{tabular}

It is clear from Table ( 9 ) that the correlation coefficient between the expressions and the overall degree of the axis to which it belongs ranges between $\left(0.764 * *\right.$ : $\left.0.912^{* *}\right)$ and all these statements are statistically significant at the level (0.05), which indicates the validity of the questionnaire. 


\section{2- Stability:}

The Researchers calculated the stability coefficient for the questionnaire using the "Alpha Cronbach" factor, by calculating the alpha coefficient for each axis as well as for the questionnaire as a whole.

$$
\text { Table (1.) }
$$

Calculation of stability using the alpha and mid-segmentation coefficients of the survey axes $(\mathbf{n}=30)$

\begin{tabular}{|c|c|c|c|c|c|}
\hline \multirow{2}{*}{ No. } & \multirow{2}{*}{ Axes } & \multirow{2}{*}{ Alpha } & \multirow{2}{*}{ COR. } & \multicolumn{2}{|c|}{ FIX.FAS. } \\
\hline & & & & SP.- BRO. & GETT. \\
\hline$\overline{1}$ & administrative regulation & $\cdot \overline{\cdot ., \Lambda \vee r ~}$ & $\cdot, \wedge \cdot 0$ & $\cdot, \wedge 9 Y$ & $\cdot, \wedge 9 \mathrm{r}$ \\
\hline 2 & technical regulation & $\cdot, V Y \cdot$ & $\cdot, 7 \times 1$ & $\cdot, \Lambda \cdot r$ & $\cdot, \vee \vee \wedge$ \\
\hline 3 & financial regulation & $\cdot, \wedge \wedge$. & $\cdot, \vee \Gamma \wedge$ & $\cdot, \wedge \leqslant 9$ & $\cdot, \wedge \cdots$ \\
\hline 4 & legislative regulation & $\cdot, \wedge \backslash \wedge$ & $\cdot, 70 Y$ & $\cdot, \vee \vee 9$. & $\cdot, \vee \wedge \varepsilon$ \\
\hline & $\mathbf{A L L}$ & $\cdot, 9 \%$ & $\cdot, \wedge \wedge \vee$ & $\cdot, 9 \leq$. & $\cdot 949$ \\
\hline
\end{tabular}

It is clear from Table $(1 \cdot)$ that the alpha coefficient of the axes ranged between (0.652: 0.940), the midterm fragmentation ranged from $(\cdot, \wedge \cdot r: 0.940)$ using Spearman, $(\cdot, \wedge . .:$ q q) using gtman, which are statistically significant coefficients at (0.05) level, which indicates that the questionnaire has high stability coefficients.

\section{Fifth: The application of the questionnaire:}

After confirming the scientific transactions of the questionnaire, the questionnaire was applied in its final form attachment (4) to the basic sample in the period form $1 / 9 / r_{.1} 9$ to $30 / 11 / r \cdot 19$.

\section{Statistical treatments for data:}

(Percentage - correlation coefficient - alpha- Cronbach - mean - standard deviation - estimated degree).

\section{Presentation, interpretation and discussion of results:}

Within the limits of the results of the two researchers and according to the study sample and data collection tools, the discussion of the results will be presented and interpreted in a way that is consistent with the aim of the research.

\section{1-What is the name, vision, mission and objectives of the unit of a special nature for the sports shows?}

\section{Table (11)}

Weighted mean and percentage of sample opinions on the questionnaire $(n=$ 160)

\begin{tabular}{|c|c|c|c|c|c|c|c|}
\hline \multirow{2}{*}{ No. } & \multirow{2}{*}{ ferries } & \multicolumn{3}{|c|}{ opinions } & \multirow{2}{*}{ W.S } & \multirow{2}{*}{ W.S.D } & \multirow{2}{*}{ percentage } \\
\hline & & AP. & S.AP. & 1.AP & & & \\
\hline 1 & Scientific Center for Sports Shows. & 17. & - & . & r, & $1, \ldots$ & $1 \ldots \%$ \\
\hline 2 & $\begin{array}{l}\text { The Scientific Center for Sports Shows is a } \\
\text { leading center at the local and regional } \\
\text { levels in providing administrative and } \\
\text { technical services and consultations for } \\
\text { sports shows. }\end{array}$ & 17. & • & • & $r, \ldots$ & $1, \cdots$ & $1 \ldots \%$ \\
\hline
\end{tabular}




\begin{tabular}{|c|c|c|c|c|c|c|c|}
\hline 3 & $\begin{array}{l}\text { The center seeks to provide services to } \\
\text { individuals and various institutions inside } \\
\text { and outside the university in the field of } \\
\text { Sports Shows to meet the diverse needs of } \\
\text { society. }\end{array}$ & 17. & . & . & $r, .$. & $1, \ldots$ & $1 \ldots \%$ \\
\hline 4 & $\begin{array}{l}\text { Conducting scientific research in the field of } \\
\text { sports performances } \\
\text { Marketing of Sports Shows. }\end{array}$ & $1 \leq 0$ & 0 & 1. & $r, \wedge \varepsilon$ & $\cdot, 90$ & $৭ \leqslant, \vee ৭ \%$ \\
\hline 5 & $\begin{array}{l}\text { Providing administrative and technical } \\
\text { consultations in the field of Sports Shows. }\end{array}$ & TrT & IV & 1. & $r, V V$ & -,94 & $৭$ ৭, ४৭\% \\
\hline 6 & $\begin{array}{l}\text { Providing training programs and courses in } \\
\text { the field of sports shows. }\end{array}$ & IT. & 17 & $1 \varepsilon$ & $r, V r$ & $\cdot, 91$ & Q., ৯r\% \\
\hline 7 & $\begin{array}{l}\text { Holding scientific seminars and conferences } \\
\text { in the field of Sports Shows. }\end{array}$ & 17. & . & $\cdot$ & $r,$. & $1, \ldots$ & $1 \ldots \%$ \\
\hline
\end{tabular}

It is clear from table ( 11$)$ that the responses of the opinions of the research sample about the questionnaire, where the percentage of phrases ranged between ( 9 r. $99 \%$ : 100\%).

By presenting the opinions of the responses of the research sample in a table ( $\mathrm{Y}$ ), it is possible to explain and discuss some of the results that have been reached:

- A name was chosen for the unit, and a vision, mission, and goals were set forth in commensurate with it Services and activities provided by the unit.

This is in agreement with the findings of a study (Aal Saad; 2018) (1).

2- What are the basic regulations for establishing the unit (administrative, technical, financial, legislative and legal)?

Table (12)

Weighted mean and percentage of sample opinions on the questionnaire $(n=$ 160)

\begin{tabular}{|c|c|c|c|c|c|c|c|}
\hline$\overline{1}$ & Dean of the College (Chairman). & 17. & $\cdot$ & 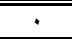 & $\bar{r}+, \cdots$ & $1, \cdots$ & $1 \cdots, \cdots$ \\
\hline 3 & Unit Director (member). & 17. & $\cdot$ & . & $r, \cdots$ & $1, \cdots$ & $1 \cdots, \cdots$ \\
\hline 6 & $\begin{array}{l}2 \text { members with technical experience in the field } \\
\text { (member). }\end{array}$ & 17. & • & · & $r, \ldots$ & $1, \ldots$ & $1 \cdots, \cdots$ \\
\hline 7 & The financial officer of the unit. & 17. & $\cdot$ & $\cdot$ & $r, \cdots$ & $1, \cdots$ & $1 \cdots, \cdots$ \\
\hline 8 & The administrative officer of the unit. & 17. & $\cdot$ & $\cdot$ & $r, \ldots$ & $1, \cdots$ & $1 \cdots, \cdots$ \\
\hline 9 & $\begin{array}{l}\text { Public Relations, Advertising, Media and Marketing } \\
\text { Unit Officer. }\end{array}$ & $1 \ldots$ & £० & 10 & r,or & $\cdot, \wedge \varepsilon$ & $\wedge \varepsilon, \Gamma \wedge$ \\
\hline 11 & $\begin{array}{l}\text { Defining the terms of reference and responsibilities and } \\
\text { describing the workers inside the unit. }\end{array}$ & 17. & · & • & $r, \ldots$ & $1, \cdots$ & $1 \cdots, \cdots$ \\
\hline 12 & $\begin{array}{l}\text { Approving the general budget project, the final } \\
\text { account, and the financial position of the unit. }\end{array}$ & 17. & • & • & $r, \ldots$ & $1, \ldots$ & $1, \ldots$ \\
\hline 13 & $\begin{array}{l}\text { Setting the annual plan for activities and programs } \\
\text { according to the needs of the community. }\end{array}$ & 17. & • & • & $r, \ldots$ & $1, \cdots$ & $1 \cdots, \cdots$ \\
\hline 14 & Carrying out all work inside the unit. & 17. & . & . & $r, \ldots$ & $1, \cdots$ & $1 \ldots, \cdots$ \\
\hline
\end{tabular}




\begin{tabular}{|c|c|c|c|c|c|c|c|}
\hline 15 & $\begin{array}{l}\text { Prepare a private database or records of activities and } \\
\text { programs. }\end{array}$ & וr. & 17 & $1 \leq$ & r, & $\cdot, 91$ & q., הr \\
\hline 16 & $\begin{array}{l}\text { Selection of the work team involved in implementing } \\
\text { programs and activities within the unit. }\end{array}$ & 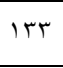 & iv & $1 \cdot$ & r,, $\mathrm{V}$ & $\cdot, 94$ & 9 १, rq \\
\hline 17 & Preparing work progress reports within the unit. & $1 \leqslant 0$ & $\circ$ & $1 \cdot$ & $r, \wedge \varepsilon$ & $\cdot, 90$ & $9 \leqslant, \vee 9$ \\
\hline 18 & $\begin{array}{l}\text { Approving the administrative, financial and technical } \\
\text { regulations within the unit. }\end{array}$ & 17. & • & • & $r, \ldots$ & $1, \ldots$ & $1, \ldots$ \\
\hline 19 & $\begin{array}{l}\text { Approval of agreements and contracts with other } \\
\text { parties after approval of the competent authorities. }\end{array}$ & iro & ro & $1 \cdot$ & r, Vr & $\cdot, 91$ & $9 \cdot, 7 r$ \\
\hline
\end{tabular}

\section{Follow Table (12)}

Weighted mean and percentage of sample opinions on the questionnaire $(n=$ 160)

\begin{tabular}{|c|c|c|c|c|c|c|c|}
\hline \multirow{2}{*}{ No. } & \multirow{2}{*}{ ferries } & \multicolumn{3}{|c|}{ opinions } & \multirow{2}{*}{ W.S } & \multirow{2}{*}{ W.S.D } & \multirow{2}{*}{ percentage } \\
\hline & & AP. & S.AP. & 1.AP & & & \\
\hline 20 & $\begin{array}{l}\text { Determine the aspects of spending for expenses and } \\
\text { revenues in light of resources. }\end{array}$ & 100 & r & r & r,97 & $\cdot, 99$ & $9 \wedge, 0 \leqslant$ \\
\hline 21 & $\begin{array}{l}\text { Propose amendments and proposals to present them to } \\
\text { the competent authorities. }\end{array}$ & IrA & it & r. & $r, 7 \uparrow$ & $\cdot, \wedge 9$ & $\wedge 9,1 \mathrm{~V}$ \\
\hline 22 & $\begin{array}{l}\text { The representative nominates the unit for assignments, } \\
\text { meetings, seminars and conferences. }\end{array}$ & $1 \ldots$ & ro & ro & $r, \leqslant V$ & $\cdot$, Ar & $\Lambda Y, r q$ \\
\hline & Jurisdictions of the board of the unit & $1 \wedge \vee 7$ & 114 & 91 & Y,А५ & $\cdot, 90$ & $90, Y V$ \\
\hline & The first axis: administrative regulation & rYOT & 101 & 1.7 & r,^q & $\cdot, 97$ & $94,0$. \\
\hline 23 & $\begin{array}{l}\text { Strengthening ties between the college and external } \\
\text { institutions and bodies. }\end{array}$ & 17. & · & · & $r, \ldots$ & $1, \ldots$ & $1 \ldots, \ldots$ \\
\hline 24 & $\begin{array}{l}\text { Contribute to the implementation of college projects in } \\
\text { the field of sports shows. }\end{array}$ & 17. & . & · & $r, \ldots$ & $1, \ldots$ & $1 \cdots, \ldots$ \\
\hline 25 & $\begin{array}{l}\text { Assisting the college in teaching and training students } \\
\text { in the field of sports shows. }\end{array}$ & $1 \leqslant V$ & IT & · & r, 9 r & $\cdot, 9 \vee$ & $9 \vee, Y q$ \\
\hline 26 & $\begin{array}{l}\text { Helping external bodies in training workers in the field } \\
\text { of sports shows }\end{array}$ & Tra & 1. & $1 \varepsilon$ & $r, V \uparrow$ & $\cdot, 94$ & $9 r, \cdot 1$ \\
\hline 27 & Conducting scientific research in the field of sports. & 90 & 10 & $\varepsilon$. & $r, r V$ & $\cdot, \times 9$ & $\vee \wedge, \wedge 9$ \\
\hline 28 & Contribute to the development of science related . & 91 & $\varepsilon$. & Tr & $r, \leqslant \wedge$ & $\cdot, \wedge r$ & NY,O. \\
\hline 29 & $\begin{array}{l}\text { Helping external bodies with scientific methods in the } \\
\text { field of sports shows. }\end{array}$ & 17. & · & • & $r, \ldots$ & $1, \ldots$ & $1 \ldots, \ldots$ \\
\hline 30 & $\begin{array}{l}\text { Contribute to training members of society through } \\
\text { scientific methods. }\end{array}$ & $1 \leqslant \Lambda$ & r & 1. & r,人 & $\cdot, 90$ & $90, \varepsilon r$ \\
\hline & Establishment goals of the unit & $11 \cdot \leq$ & $\Lambda$. & $\wedge \uparrow$ & $r, \wedge$. & $\cdot, 94$ & qr,rq \\
\hline 31 & $\begin{array}{l}\text { Supporting and maximizing the role of colleges of } \\
\text { physical education towards society and environmental } \\
\text { development. }\end{array}$ & 17. & · & · & $r, \ldots$ & $1, \ldots$ & $1, \ldots$ \\
\hline 32 & $\begin{array}{l}\text { Maximizing the role of sports shows in community } \\
\text { service and environmental development. }\end{array}$ & 17. & . & · & $r, \ldots$ & $1, \cdots$ & $1 \cdots, \ldots$ \\
\hline 33 & $\begin{array}{l}\text { Promoting the educational, research and applied } \\
\text { process in the field of sports shows. }\end{array}$ & $9 \wedge$ & 纟o & iv & $r, 01$ & $\cdot, \wedge \varepsilon$ & $\Lambda T, 0 \leqslant$ \\
\hline 34 & Linking theory to practice in sports shows. & 17. & $\cdot$ & $\cdot$ & $r, \ldots$ & $1, \cdots$ & $1 \cdots, \cdots$ \\
\hline 35 & $\begin{array}{l}\text { Highlighting the value of science and its importance in } \\
\text { working life in the field of sports shows. }\end{array}$ & 1.0 & $\varepsilon$. & 10 & r,07 & $\cdot, \wedge 0$ & $10, \leqslant Y$ \\
\hline 36 & $\begin{array}{l}\text { Increasing students' skills while studying in the field of } \\
\text { sports shows. }\end{array}$ & $1 \cdots$ & ro & ro & $r, \leqslant V$ & $\cdot, \wedge r$ & $\Lambda Y, r q$ \\
\hline 37 & Raising the efficiency of workers in the field of offers. & 100 & 0 & $\cdot$ & r,9V & $\cdot, 99$ & $9 \wedge, 97$ \\
\hline 38 & $\begin{array}{l}\text { Opening new horizons for work in the field of sports } \\
\text { shows. }\end{array}$ & 17. & · & • & $r, \ldots$ & $1, \ldots$ & $1, \ldots$ \\
\hline 39 & $\begin{array}{l}\text { Providing new resources to increase the self-resources } \\
\text { of physical education colleges. }\end{array}$ & 17. & . & - & $r,$. & $1, \cdots$ & $1, \ldots$ \\
\hline \multicolumn{2}{|r|}{ Rules and principles of the unit } & $1 Y 01$ & iro & $\Delta V$ & $r, \wedge r$ & $\cdot, 9 \leqslant$ & $9 \leqslant, \leqslant V$ \\
\hline 40 & $\begin{array}{l}\text { Conducting scientific research in the field of sports } \\
\text { shows. }\end{array}$ & 1To & 10 & 1. & $r, \mathrm{r} \wedge$ & • & $9 r, V)$ \\
\hline 41 & $\begin{array}{l}\text { Providing research consultancy in the field of sports } \\
\text { shows. }\end{array}$ & 11. & r. & r. & r,07 & $\cdot, \wedge 0$ & $10, \varepsilon r$ \\
\hline 42 & $\begin{array}{l}\text { Providing technical and administrative consultations in } \\
\text { the field of sports shows. }\end{array}$ & 17. & - & • & $r, \ldots$ & $1, \cdots$ & $1, \ldots$ \\
\hline 43 & $\begin{array}{l}\text { Providing, preparing and qualifying specialists and } \\
\text { leaders in the field of sports shows. }\end{array}$ & $10 \mathrm{~V}$ & r & 1 & r,१९ & $\cdot, 99$ & $99,1 \vee$ \\
\hline 44 & $\begin{array}{l}\text { Preparing professional development programs for } \\
\text { workers in the field of sports shows. }\end{array}$ & IrV & rt & · & r,人т & $\cdot, 90$ & $90, r_{1}$ \\
\hline
\end{tabular}




\begin{tabular}{|c|c|c|c|c|c|c|c|}
\hline 45 & $\begin{array}{l}\text { Implementing training and qualification programs for } \\
\text { workers in the field of sports shows. }\end{array}$ & 149 & 11 & 1. & $r, \wedge)$ & $\cdot, 9 \leq$ & $94,0 \leqslant$ \\
\hline 46 & Designing programs and projects for different parties. & 17. & . & $\cdot$ & $r, \ldots$ & $1, \cdots$ & $1 \cdots, \cdots$ \\
\hline 47 & $\begin{array}{l}\text { Incorporation of specialized cadres in sports shows to } \\
\text { serve the community. }\end{array}$ & 101 & r & $\cdot$ & r,१९ & $1, \cdots$ & 99,01 \\
\hline
\end{tabular}

\section{Follow Table (12)}

Weighted mean and percentage of sample opinions on the questionnaire $(n=$ 160)

\begin{tabular}{|c|c|c|c|c|c|c|c|}
\hline \multirow{2}{*}{ No. } & \multirow{2}{*}{ ferries } & \multicolumn{3}{|c|}{ opinions } & \multirow{2}{*}{ W.S } & \multirow{2}{*}{ W.S.D } & \multirow{2}{*}{ percentage } \\
\hline & & AP. & S.AP. & 1.AP & & & \\
\hline 48 & $\begin{array}{l}\text { Linking the unit to the community's developmental, } \\
\text { educational and professional needs. }\end{array}$ & $10 \mathrm{~V}$ & $r$ & • & $r, 91$ & $\cdot, 99$ & $99, \Gamma \wedge$ \\
\hline 49 & $\begin{array}{l}\text { Participate in raising awareness and spreading a culture } \\
\text { of community service. }\end{array}$ & 100 & $r$ & r & $r, 97$ & $\cdot, 99$ & $9 \wedge, 0 \leq$ \\
\hline 50 & $\begin{array}{l}\text { Holding seminars, conferences and workshops in the } \\
\text { field of sports shows. }\end{array}$ & 17. & · & . & $r, \ldots$ & $1, \ldots$ & $1 \ldots, \ldots$ \\
\hline 51 & $\begin{array}{l}\text { Providing sources of knowledge and creating databases } \\
\text { on sports shows. }\end{array}$ & $1 \leq \varepsilon$ & 1. & 7 & Y,Aт & $\cdot, 90$ & $90, \leqslant r$ \\
\hline 52 & $\begin{array}{l}\text { Providing the necessary human and material } \\
\text { capabilities to manage and organize sports shows }\end{array}$ & 17. & $\cdot$ & • & $r, \ldots$ & $1, \ldots$ & $1 \ldots, \ldots$ \\
\hline 53 & $\begin{array}{l}\text { (Participants - Design - Clothing - Instruments - Music } \\
\text { - Profiles - Directing) }\end{array}$ & 107 & $\varepsilon$ & • & $r, 91$ & $\cdot, 99$ & $99,1 \vee$ \\
\hline 54 & Establishing sports shows marketing forums. & 100 & 0 & $\cdot$ & r,qV & $\cdot, 99$ & 91,97 \\
\hline 55 & $\begin{array}{l}\text { Organizing training courses, seminars and conferences } \\
\text { to market sports shows. }\end{array}$ & 17. & • & $\cdot$ & $r, \ldots$ & $1, \ldots$ & $1 \cdots, \cdots$ \\
\hline & Tasks and activities of the unit & $r \leq \cdot r$ & 1.1 & $\leqslant 9$ & $r, 9 r$ & $\cdot, 9 \mathrm{~V}$ & qV,rr \\
\hline & Second axis: technical regulation & $\sum \vee 70$ & mir & $19 r$ & $r, \wedge \mathrm{V}$ & $\cdot, 97$ & 90,09 \\
\hline 56 & $\begin{array}{l}\text { The finance officer prepares the unit's budget plan for } \\
\text { presentation to the Board of Directors. }\end{array}$ & 100 & $\circ$ & • & r, $9 \mathrm{~V}$ & $\cdot, 99$ & $9 \wedge, 97$ \\
\hline 57 & $\begin{array}{l}\text { Budget is prepared in the style of budgets for public } \\
\text { service agencies. }\end{array}$ & 17. & • & • & $r, \cdots$ & $1, \cdots$ & $1, \ldots$ \\
\hline 58 & $\begin{array}{l}\text { It is approved by the Board of Directors for approval } \\
\text { by the University Council. }\end{array}$ & 17. & $\cdot$ & • & $r, \ldots$ & $1, \cdots$ & $1 \cdots, \cdots$ \\
\hline 59 & The budget begins and ends with the state's fiscal year. & 17. & $\cdot$ & $\cdot$ & $r, \cdots$ & $1, \cdots$ & $1 \cdots, \cdots$ \\
\hline 60 & $\begin{array}{l}\text { The plan includes the internal budget (wages - bonuses } \\
\text { - incentives - revenue). }\end{array}$ & 17. & • & • & $r, \ldots$ & $1, \ldots$ & $1 \cdots, \ldots$ \\
\hline 61 & $\begin{array}{l}\text { The plan includes the external budget after approval by } \\
\text { the University Council, which is: }\end{array}$ & 17. & $\cdot$ & • & $r, \ldots$ & $1, \cdots$ & $1 \cdots, \cdots$ \\
\hline 62 & $\begin{array}{l}\text { (Donations - donations - interest on deposits and } \\
\text { investments) }\end{array}$ & 17. & • & $\cdot$ & $r, \ldots$ & $1, \ldots$ & $1 \cdots, \cdots$ \\
\hline 63 & Unit statements and accounts are prepared. & 17. & $\cdot$ & $\cdot$ & $r, \cdots$ & $1, \ldots$ & $1 \cdots, \cdots$ \\
\hline 64 & $\begin{array}{l}\text { The calculations are subject to internal control from } \\
\text { exchange and collection. }\end{array}$ & 109 & 1 & . & r, 99 & $1, \ldots$ & $99, \vee 9$ \\
\hline 65 & $\begin{array}{l}\text { The disbursement from the unit's account is made by } \\
\text { check. }\end{array}$ & 17. & • & • & $r, \ldots$ & $1, \cdots$ & $1 \ldots, \ldots$ \\
\hline 66 & $\begin{array}{l}\text { Checks are issued after reviewing the unit's financial } \\
\text { officer and attaching all documents supporting the } \\
\text { exchange process. }\end{array}$ & 17. & • & • & $r, \ldots$ & $1, \ldots$ & $1 \ldots, \ldots$ \\
\hline 67 & $\begin{array}{l}\text { Checks are approved by signing the dean of the college } \\
\text { and the secretary of the college. }\end{array}$ & 17. & . & • & $r, \ldots$ & $1, \ldots$ & $1 \ldots, \ldots$ \\
\hline 68 & $\begin{array}{l}\text { All unit expenses are subject to taxes and stamp duty } \\
\text { according to laws. }\end{array}$ & 10. & 0 & 0 & $r, q 1$ & $\cdot, 9 \vee$ & $97, \wedge \wedge$ \\
\hline 69 & $\begin{array}{l}\text { The finance officer supplies the expenses to the } \\
\text { competent authorities in accordance with the laws. }\end{array}$ & 17. & . & . & $r, \ldots$ & $1, \cdots$ & $1 \cdots, \ldots$ \\
\hline 70 & $\begin{array}{l}\text { Supplying the percentage prescribed by the University } \\
\text { Council for each activity separately for the account of } \\
\text { the Ministry of Finance, special funds and the } \\
\text { Community Service and Environment Development } \\
\text { Fund at the university. }\end{array}$ & $10 \mathrm{~V}$ & $r$ & · & $r, 91$ & $\cdot, 99$ & $99, \Gamma \wedge$ \\
\hline 71 & $\begin{array}{l}\text { The net revenue is distributed at (5\% the Ministry of } \\
\text { Finance }-10 \% \text { of the university }-20 \% \text { of the college - } \\
20 \% \text { of unit account support }-35 \% \text { of the work team - } \\
10 \% \text { of the Board of Directors). }\end{array}$ & $1 \cdots$ & 10 & $\leq 0$ & $r, r \leqslant$ & $\cdot, \mathrm{VA}$ & $\vee \wedge, 1 \Gamma$ \\
\hline 72 & $\begin{array}{l}\text { Marketing and advertising does not exceed } 10 \% \text { of the } \\
\text { internal budget. }\end{array}$ & 1.9 & $r \cdot$ & r) & $r, \leqslant q$ & $\cdot, \wedge \Gamma$ & NY,qr \\
\hline 73 & $\begin{array}{l}\text { The financial officer is responsible for receiving the } \\
\text { permanent advance from the unit. }\end{array}$ & $11 \mathrm{~V}$ & $r$. & 14 & r, 70 & $\cdot, \wedge \wedge$ & A^,rr \\
\hline
\end{tabular}




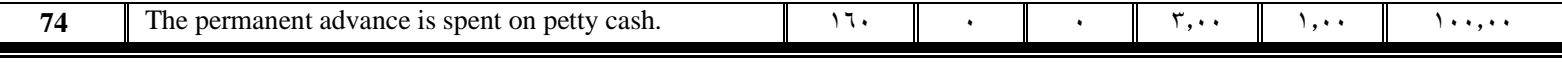

\section{Follow Table (12)}

Weighted mean and percentage of sample opinions on the questionnaire $(n=$ 160)

\begin{tabular}{|c|c|c|c|c|c|c|c|}
\hline \multirow{2}{*}{ No. } & \multirow{2}{*}{ ferries } & \multicolumn{3}{|c|}{ opinions } & \multirow{2}{*}{ W.S } & \multirow{2}{*}{ W.S.D } & \multirow{2}{*}{ percentage } \\
\hline & & AP. & S.AP. & 1.AP & & & \\
\hline 75 & $\begin{array}{l}\text { Do not use the petty cash amount for wages, incentives, } \\
\text { or rewards. }\end{array}$ & 11. & $\varepsilon \cdot$ & $1 \cdot$ & r & $\cdot, \wedge \wedge$ & $\wedge \vee, 0$ \\
\hline 76 & $\begin{array}{l}\text { Follow legal and administrative procedures in } \\
\text { disbursing and settling the permanent advance. }\end{array}$ & 17. & • & · & $r, \ldots$ & $1, \cdots$ & $1 \cdots, \cdots$ \\
\hline 77 & $\begin{array}{l}\text { The temporary advance is made in the event that the } \\
\text { checks cannot be disbursed. }\end{array}$ & $1 \cdots$ & 0. & $1 \cdot$ & r,0T & $\cdot, 10$ & 10, $\Sigma Y$ \\
\hline 78 & $\begin{array}{l}\text { The needs of the unit can be purchased by direct order, } \\
\text { tender, or practice in accordance with Law (89) for the } \\
\text { year 1998 AD in accordance with the provisions of the } \\
\text { executive regulations of the Universities Organizing } \\
\text { Law, upon a proposal from the Unit's Board of } \\
\text { Directors and approved by the President of the } \\
\text { University. }\end{array}$ & 17. & • & • & $r, \ldots$ & $1, \ldots$ & $1, \ldots$ \\
\hline 79 & $\begin{array}{l}\text { The finance officer reviews the final accounts and } \\
\text { sends them to the Special Funds Unit and the Follow- } \\
\text { up Management Unit of a special nature in the } \\
\text { university's social service sector. }\end{array}$ & 17. & • & · & $r, \ldots$ & $1, \ldots$ & $1 \cdots, \ldots$ \\
\hline 80 & $\begin{array}{l}\text { Post the surplus of the remaining revenues from the } \\
\text { ending fiscal year to the following years. }\end{array}$ & $10 \mathrm{~V}$ & r & • & r,१人 & $\cdot, 99$ & 99, ґ \\
\hline & Third axis: financial regulation & rvis & IVY & $11 \leq$ & r,q. & $\cdot, 9 \mathrm{~V}$ & $94,7 \vee$ \\
\hline 81 & $\begin{array}{l}\text { Article (307) of the executive regulations of the } \\
\text { Universities Organization Law establishing the unit in } \\
\text { an independent administrative and financial capacity by } \\
\text { a decision of the University Council. }\end{array}$ & 17. & . & • & $r, .$. & $1, \ldots$ & $1 \ldots, \ldots$ \\
\hline 82 & $\begin{array}{l}\text { Article (308) of the executive regulations of the } \\
\text { Universities Organizing Law that the unit achieves the } \\
\text { goals mentioned in the text of the article. }\end{array}$ & 17. & • & • & $r, \ldots$ & $1, \ldots$ & $1 \ldots, \ldots$ \\
\hline 83 & $\begin{array}{l}\text { Article (309) of the executive regulations of the law } \\
\text { regulating universities, each unit has a special account } \\
\text { in one of the accredited banks after the approval of the } \\
\text { university council, in which all its resources are } \\
\text { deposited. }\end{array}$ & 17. & . & · & $r, \ldots$ & $1, \ldots$ & $1 \ldots, \ldots$ \\
\hline 84 & $\begin{array}{l}\text { Article (310) of the executive regulations of the } \\
\text { Universities Organizing Law. The unit shall perform the } \\
\text { activities and activities of the college affiliated to it } \\
\text { without charge, while the rest of the authorities, whether } \\
\text { inside or outside the university, will be paid for a fee. }\end{array}$ & 17. & • & · & $r, \ldots$ & $1, \ldots$ & $1 \ldots, \ldots$ \\
\hline 85 & $\begin{array}{l}\text { Article }(311) \text { of the executive regulations of the law } \\
\text { regulating universities is managed by the unit a board of } \\
\text { directors expressing the goals that the unit seeks to } \\
\text { achieve. }\end{array}$ & 17. & • & • & $r, \ldots$ & $1, \ldots$ & $1 \ldots, \ldots$ \\
\hline 86 & $\begin{array}{l}\text { Article (311) of the executive regulations of the } \\
\text { Universities Organizing Law, the term of the council } \\
\text { ranges from three years, renewable once. }\end{array}$ & 17. & . & · & $r, \ldots$ & $1, \ldots$ & $1 \ldots, \ldots$ \\
\hline 87 & $\begin{array}{l}\text { Article (311) of the executive regulations of the law } \\
\text { regulating universities. The university president } \\
\text { appoints the director of the unit and all members are } \\
\text { nominated by the dean of the college. }\end{array}$ & 17. & . & · & $r, \ldots$ & $1, \ldots$ & $1 \ldots, \ldots$ \\
\hline 88 & $\begin{array}{l}\text { Article (311) of the executive regulations of the law } \\
\text { regulating universities must not occupy the center } \\
\text { director with any other administrative positions in the } \\
\text { college or university. }\end{array}$ & 17. & • & • & $r, \ldots$ & $1, \ldots$ & $1 \ldots, \ldots$ \\
\hline 89 & $\begin{array}{l}\text { Article (311) of the executive regulations of the Law on } \\
\text { Universities Regulation finds that the Council includes } \\
\text { members from abroad with technical expertise in the } \\
\text { field. }\end{array}$ & 17. & · & · & $r, \ldots$ & $1, \cdots$ & $1 \ldots, \ldots$ \\
\hline 90 & $\begin{array}{l}\text { Article (311) of the executive regulations of the } \\
\text { Universities Regulatory Law. The Board of Directors } \\
\text { has the dominant authority over unit affairs. }\end{array}$ & 17. & - & · & $r, .$. & $1, \ldots$ & $1 \ldots, \ldots$ \\
\hline
\end{tabular}

Follow Table (12)

Weighted mean and percentage of sample opinions on the questionnaire $(n=$ 
160)

\begin{tabular}{|c|c|c|c|c|c|c|c|}
\hline \multirow{2}{*}{ No. } & \multirow{2}{*}{ ferries } & \multicolumn{3}{|c|}{ opinions } & \multirow{2}{*}{ W.S } & \multirow{2}{*}{ W.S.D } & \multirow{2}{*}{ Per. } \\
\hline & & AP. & S.AP. & 1.AP & & & \\
\hline 91 & $\begin{array}{l}\text { Article (312) of the executive regulations of the Universities } \\
\text { Organizing Law. The decisions of the Board of Directors are } \\
\text { communicated to the Vice Chancellor for Community Affairs } \\
\text { and Environmental Development within (8) days at the most } \\
\text { from the date of its issuance for approval by the University } \\
\text { President. }\end{array}$ & 17. & • & • & $r, \ldots$ & $1, \cdots$ & $1 \cdots, \cdots$ \\
\hline 92 & $\begin{array}{l}\text { Article (313) of the executive regulations of the law } \\
\text { regulating universities is concerned with the unit's resources } \\
\text { in foreign exchange for its service of direct import through } \\
\text { the bank in which its resources are deposited. }\end{array}$ & 17. & • & • & $r, \ldots$ & $1, \cdots$ & $1 \cdots, \ldots$ \\
\hline 93 & $\begin{array}{l}\text { Article (314) of the executive regulations of the law } \\
\text { regulating universities. The unit shall have an internal } \\
\text { regulation specifying the functions of the council, the council } \\
\text { chairman, and the financial and administrative systems of the } \\
\text { unit. }\end{array}$ & 17. & • & • & $r, \ldots$ & $1, \ldots$ & $1 \ldots, \ldots$ \\
\hline 94 & $\begin{array}{l}\text { The provisions of Law No. (49) of } 1972 \text { regarding the } \\
\text { organization of universities and its regulations shall apply in } \\
\text { the absence of a special text for this unit. }\end{array}$ & 17. & • & • & $r, \ldots$ & $1, \cdots$ & $1 \ldots, \cdots$ \\
\hline 95 & $\begin{array}{l}\text { The work of the unit is subject to the supervision of the } \\
\text { university's competent bodies, the central auditing agency, } \\
\text { and the state's supervisory organs. }\end{array}$ & 17. & • & • & $r, \ldots$ & $1, \cdots$ & $1 \cdots, \cdots$ \\
\hline \multicolumn{2}{|c|}{ Fourth axis : legislative regulation } & $r \leq \ldots$ & - & · & $r, \ldots$ & $1, \ldots$ & $1 \ldots, \ldots$ \\
\hline & ALL & $1 \leq 1 \leq 0$ & $7 \varepsilon r$ & $\& 1 Y$ & r, 9 . & $\cdot, 9 V$ & $97, \vee \wedge$ \\
\hline
\end{tabular}

It is clear from table (12) that the responses of the opinions of the research sample about the questionnaire, where the percentage of phrases ranged between ( $\vee \wedge .1 \% \%$ : 100\%), and the percentage of axes as a whole ranged $(93 . r 9 \%: 1 \cdots \%)$.

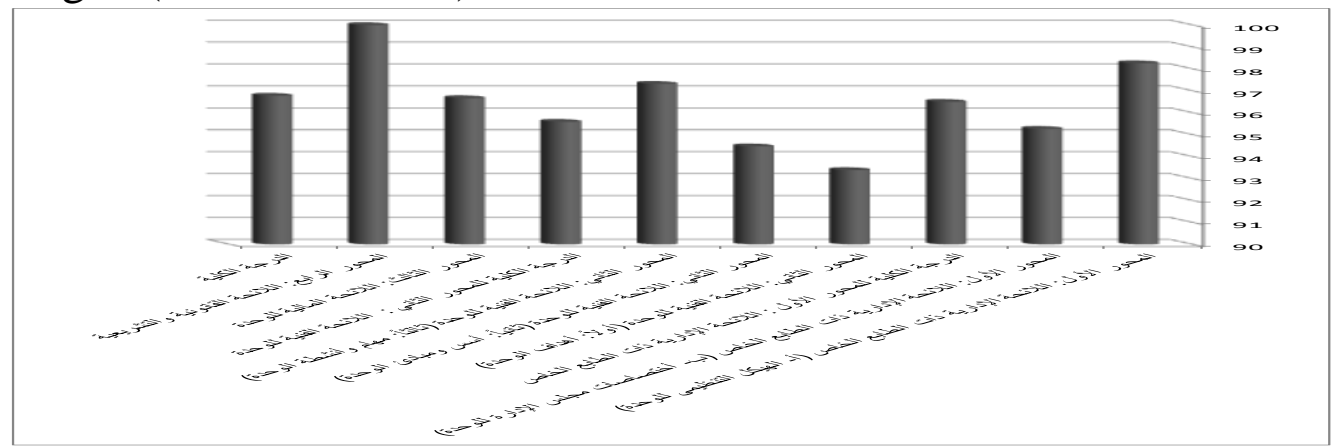

\section{Figure (1) Percentage of weighted averages of the questionnaire}

By presenting the opinions of the responses of the research sample in a table (12), it is possible to explain and discuss some of the results that have been reached:

\section{The first major axis: the administrative regulations:}

- The organizational structure of the unit consists of faculty members who specialize in the field of sports shows in the faculty and they are responsible for the workflow of the unit and the activities that will be carried out.

The board of directors is at a high level of competence in the same field of specialization, and they should be taken care of through human and 
professional development in the same field. ( 1 ^: 210)

- The board of directors of special units must also include members from outside the academic institution with experience in the same specialty of the unit, which helps to create other channels of communication with the community and meet its services, and this was confirmed by the results of (Zahm; 2016) ( $(\cdot)$.

- Public Relations, Advertising, Media and Marketing Officer for the unit, where (Al-Jamal; 2012) (9) indicates that there must be a member within the board of directors responsible for preparing the marketing plan for the tasks and activities of the special units, and that he has the ability, experience and competence in this field, as he should be a source to support the link with the community.

- The unit's board of directors is concerned with setting general policy and plans for work within the unit, as there is a clear plan to serve the community as (Muhammad; 2017) ( $Y \varepsilon$ ) indicates that they develop the community services provided by the units, and the members of the board of directors should not abuse the granted authority and obstruct the work.

\section{The second axis: Technical Regulations:}

the special units seek to achieve varied goals, as the study of (Gondaa; 2014) ( $I V$ ) and (Saad; 2018) ( 1 ) showed that universities sought to establish special units as a necessity to provide various service activities to different community institutions, and to participate in the development Its human resources, providing the community's needs for qualified and trained cadres, and providing support services for students to develop their skills and prepare them for the labor market.

- The unit seeks to provide new resources to increase the self-resources of the physical of physical education, and self-financing, as indicated by (Al-Asmai; 2019) ( $(r)$ and (Isaac; 2017) $(r)$ is all the revenues achieved by the sports authority, where these resources are numerous and differ from one sports administration to another, where the bodies strive to provide Sources of self-financing to improve the level of services in it, and the need to pay attention to spreading awareness of the importance of self-financing within student welfare offices to raise the level of various student activities.

The two researchers agrees with (Al-Hanashly;2012) $(\wedge)$ and (Abu Dhaif; 2018) ( 7 ) that relying on government funding as the main source of the annual budget of anybody or institution does not meet the necessary financial obligations to achieve the goals, so it must search for self-sources to support the budget and achieve the goals.

- The special productive and service units are adopted as the results of the study of (Al-Jamal; 2012) ( 9 ) reached in its work two pillars. The first is the actual participation in providing services and consultations and setting 
the experiences of the faculty members and their research capabilities in order to achieve the university's mission in serving the community, while the second pillar is participation in providing of financial resources for the operation of the units and the university's participation in financing its projects.

- included The tasks and activities of the unit in the field of marketing, as this requires setting up forums for training courses, conferences, seminars and conducting agreements and protocols, and this come along with the results of the (Sami; 2011) ( $\left.{ }^{\bullet}\right)$ that marketing is one of the most important areas that must be taken care of in order to make progress and development in the field of sports shows.

\section{The third axis: the financial regulations:}

- The unit derived its work from financial independence, whereby the general budget of the unit is prepared in the style of budgets for service public bodies, and the statements and accounts of the unit are prepared, and that the special units have an accounting system consistent with the goal of their establishment, and this is confirmed by the results of the study of (Salam; 2015) ( $\varepsilon$ ) and (Ghazi; 1997) (I צ) and (Al-Baz; 1990) (v).

- The unit's work is also subject to the supervision of the competent authorities of the university, the central accounting system, and the state's supervisory organs, which contributes to assessing the performance of special units for their roles and directs efforts to improve and develop the unit to meet the requirements of community development and service, and this is confirmed by the results of the study of (Selim; Al-Shaer; Abbas ; Sayed; 2018) ( $r \vee$ ) and (Abdel Bar; 2016) ( $r)$.

- The plan includes the external budget after the approval of the University Council, as (Mohammad; 2010) (30) and (Al-Abidin; 2002) ( $M$ ) indicated that it is possible to rely on the external budget such as gifts, donations, or interest in deposits and investments as sources of selffinancing for universities.

\section{Fourth Theme: Legal and Legislative Regulations:}

- special Units are based on their origin, form, activity, goals and relationships on a legal basis that represents the legal and legislative framework for these units financially, administratively and accounting, as this requires a set of laws and regulations regulating them and ensuring their legitimacy in practicing tasks and activities. ( $Y$ : 333 )

This is what the researchers followed when setting the main regulation of the unit, as it used many of the laws and regulations necessary to establish the unit, including the directory of special units (13) and the law of university organization and its executive regulations ( 7 , and this is consistent with the results of the study of each of (Saad; 
2018) (1) And (Hussein; Al-Zahri; Shalaby; 2014) (19) and (AlShafei; 2010) (7).

\section{Conclusions:}

- Support and maximize the role of faculties of physical education towards society and environmental development.

- Establishing units of a special nature to provide services that suit the requirements and needs of society.

- Putting a name, vision, mission, and goals for the unit commensurate with the activities and programs it offers.

- Preparing professional development programs for workers in the field of sports shows.

- Development of administrative, technical, financial, legal and legislative regulations for special units.

- Giving powers to the Board of Directors of the units of a special nature to manage the affairs of the unit.

- The diversity, multiplicity of specialties and experiences of members of the Board of Directors of special units.

- Preparing plans and programs to meet the requirements of the labor market in the field of sports shows.

- Preparing professional and human development programs for workers in the field of sports shows.

\section{Recommendations:}

- Activating the role of special units in serving the community and developing the environment.

- The diversity and multiplicity of activities and services provided by special units in universities.

- Reconsidering some of the regulations and laws that organizing units

- Doing more researches in the fields related to sports shows.

\section{References:}

1- Aal Saad, Iman Abdel (2018): Activating the role of special units in Egyptian universities in improving student service, Master Thesis, Girls College of Arts, Sciences and Education, Ain Shams University.

2-Abdeen, Mahmoud Abbas (2013): Education planning issues and economics between global and local, Egyptian Lebanese House, Cairo.

3-Abdel Bar, Nesma Abdel Rasoul (2016): A proposed strategy for developing financial resources in Egyptian universities in the light of the experience of the Republic of South Africa, $\mathrm{PhD}$ thesis, Faculty of Education, Benha University. 
4- Abdel Salam, Imad Abdel-Hakim (2015): The role of centers and units of a special nature at Zagazig University in the human development of the local community, Master Thesis, College of Education, Zagazig University.

5-Abdel-Samie,Heba Abdel-Aziz (2011): A Proposed Strategy for Marketing Sports Show Services, Master Thesis, Faculty of Physical Education for Girls, Zagazig University.

6- Abu Deif, Mahmoud Ahmed (2018): Self-financing and its role in advancing the services and activities of the Union of Sports Professions in the Arab Republic of Egypt, Master Thesis, Faculty of Physical Education for Boys, Helwan University.

7-Al-Baz, Mustafa Ali (1990): Development of Accounting in Units of a Special Nature in Universities, Scientific Production, Scientific Journal of Economics and Trade, No. 1, Faculty of Commerce, Ain Shams University.

8-Al-Hanashly,Ibrahim Mohamed (2018): Suggested alternatives to finance university education in the Republic of Yemen in the light of some contemporary global trends, PhD thesis, Faculty of Education, Ain Shams University.

9- Al-Jamal, Amal Abdul Mardi (2012): planning to market units of a special nature at Helwan University, scientific production, the twenty-fifth conference (the future of social service in the shadow of the modern civil state), Faculty of Social Work, University of Helwan.

10- Arnold, W William (2018): Strengthening College Support Services To Improve Student Transitioning To Careers, Journal of College Teaching \& Learning, Pepperdine University, USA, $\mathrm{V}(15), \mathrm{N}(1)$.

11- Awad, Mayada El-Sayed (2018): The role of university units of a special nature in community service and environmental development, Journal of Arab Studies in Education and Psychology, No. (104), Association of Arab Educators, Cairo.

12- Azab, Mohamed Ali (2011): University Education and Development Issues, The Anglo Egyptian Library, Cairo.

13- Bakry, Adel Abdel-Tawab، Zaghloul, Tharwat Saad (2006): The Law on Organizing Universities and its Executive Regulations, The General Authority of Al Amiria Printing Press, Cairo.

14- Directory of Specialized Units (2012): Community and Environmental Affairs Sector, Ain Shams University.

15- El-Shafei, Ayman Ahmed (2010): developing university units of a special nature in the light of contemporary administrative thought, $\mathrm{PhD}$ thesis, Faculty of Education, Beni Suef 
University.

16- Ghazi, Ahmed Ali (1997): A suggested accounting method for maximizing the role of units of a special nature through the concepts of strategic management accounting, scientific production, the Egyptian Journal of Commercial Studies, Volume (12), No. (3), Faculty of Commerce, University.

17- Gondaa, G. Mahadappa (2014): Role Of Educational Institutions In Shaping The Future Of Business And Society, Procedia Economics and Finance, N (11).

18- Haji, Ahmed Ismail ، Abdel Hamid, Hossam Hamad (2012): University and Human Development, World of Books, Cairo.

19- Hussein, Muhammad Rehan، Al-Zahri, Alaa Fathi ، Shalaby, Samah Sami (2014): The nature of units of a special nature and their importance in developing self-resources in universities, scientific production, Scientific Journal of Research and Commercial Studies, Volume (28), No. (1), College of Commerce and Business, Helwan University.

20- Ishaq,Basem Fouad (2017): A proposed model of self-financing for the care offices of university students in the Arab Republic of Egypt, Master Thesis, Faculty of Physical Education, Minia University.

21- Issa, Iman Mustafa (2018): A proposed strategy to activate the partnership between Palestinian universities in the West Bank and civil society institutions in the light of quality standards, Ph.D. thesis, Girls College of Arts and Educational Sciences, Ain Shams University.

22- Mabrouk, Ghada Adel (2019): The financial and administrative independence of some international universities and the possibility of benefiting from them at the University of the Suez Canal, Master Thesis, College of Education, Suez Canal University.

23- Mahrous, Muhammad Al-Asmai (2019): Suggested alternatives to diversify sources of financing higher education in the Arab countries in light of my visions of Egypt and Saudi Arabia 2030, scientific production, the educational journal of the Faculty of Education, No. (59), Faculty of Education, Sohag University.

24- Mohamed, Gehan Lotfy (2017): Envisioning a proposal based on the Pfeiffer model for developing societal services provided by the Faculty of Kindergarten for Child Care Institutions in Port Said Governorate, Scientific Production, Arab Research Journal in Specific Education, No. (6). 
25- Mohammad, Samah Zakariya (2010) : A Futuristic Vision For Developing The University Special Units For The Service of The Community , N(17).

26- Mostafa, Azmy Abdel-Khalek (2015): New in modern and contemporary sports festivals for the educational and private sectors, Dar Al-Maarif facility, Alexandria.

27- Salim, Mona Ahmed، Al-Shaer, Amira Mahmoud ، Abbas, Ahmed Ahmed، Abdel Basset, Sami El-Sayed (2018): Financial evaluation of units of a special nature, Faculty of Agriculture, Suez Canal University, Scientific Production, Journal of Agricultural Economics and Rural Development, Volume (4), No. (1), Scientific Society of Agricultural Sciences, Suez Canal University.

28- Shaari, Roziana، Rajab, Azizah (2018): The Impact of University Social Responsibility towards Producing Good Citizenship Evidence from Malaysia, International Journal of Organizational Leadership, Faculty of Management, University Technology Malaysia ,N (7).

29- Tolba, Jaber Mahmoud (1999): Educational Renewal for the Future of the University, Al-Iman Library, Mansoura.

30- Zaham, Radwan Ali (2016): Activating the role of the productive units in the colleges of the arts to develop awareness among the Arab community about the traditional arts of archaeological sites, scientific production, the Fourth International Conference, Faculty of Applied Arts, Cairo University.

31- Zain El-Abidine, Mohamed Shams El-Din (2002): The role of fundraising campaigns, grants and units of a special nature as sources of funding for the university, scientific production, Journal of Research in Education and Psychology, Volume (15), No. (3), Faculty of Education, Mania University. 